\title{
Evaluation of Quality Protein Maize Hybrids for Yield, Association of Yield with its Components and other Agronomic Traits at Bako, Ethiopia
}

\author{
Niguse Motuma ${ }^{1}$, Hirpa Legesse ${ }^{2^{\star}}$ and Legesse Wolde ${ }^{3}$ \\ ${ }^{1}$ Gobu Seyo Woreda Land Rural and Environmental Protection Office, Gobu Seyo, \\ East Wollega Zone, Ethiopia \\ ${ }^{2}$ Department of Plant Sciences, Wollega University, Post Box No: 395, Nekemte, Ethiopia \\ ${ }^{3}$ Bako Maize Improvement Centre, Ethiopian Institute of Agricultural Research, Bako, Ethiopia
}

\begin{tabular}{|c|c|}
\hline Abstract & Article Information \\
\hline $\begin{array}{l}\text { Maize is an important food, feed, as well as raw material for producing high-quality protein and } \\
\text { carbohydrates products in Africa including Ethiopia. The study was initiated with the objectives } \\
\text { to evaluate quality protein maize pipeline varieties in terms of yield and yield related traits, and } \\
\text { to investigate association of yield with its components and other desirable traits at Bako. } \\
\text { Eighteen genotypes were planted in randomized complete block design with three replications. } \\
\text { Highly significant difference were observed among the genotypes to } 50 \% \text { male flowering, } \\
\text { days to } 50 \% \text { female flowering, maturity date, ears length and grain yield. Phenotypic } \\
\text { coefficient of variation (PCV) was higher in magnitude than the genotypic coefficient of } \\
\text { variation (GCV) in respect to all the characters: The character leaf area index, grain yield, } 100 \\
\text { seed weight showed moderate PCV and GCV. Whereas male flowering date, female flowering } \\
\text { date, days to maturity, plant height, ears height, ears diameter, number of kernel rows, and } \\
\text { number of kernel ears showed low PCV and GCV. Heritability in broad sense was higher for } \\
\text { male flowering date, female flowering date, days to maturity, plant height, grain yield, hundred } \\
\text { seed weight and ears length. However, low heritability was recorded for leaf area index, } \\
\text { number of kernel per ears and ears diameters. Based on variability study genotype BH540, } \\
\text { BH542, BH543, Kuleni } 2 \text {, and Obta, were identified as early in maturity; hence these can be } \\
\text { used for developing early maturing genotypes. In present studies genotypic and phenotypic } \\
\text { correlation of seed yield was positive and significantly related with, Leaf area index, Number of } \\
\text { kernel per rows. This suggests that while selecting for improvement in seed yield is performed, } \\
\text { this character can be kept in mind provided that the character should show high variability, } \\
\text { which is the basis for selection to develop good quality protein maize. Improvement in seed } \\
\text { yield could be achieved by direct or indirect selection for high grain yielding genotypes or for } \\
\text { yield components positively associated to yield. It is expected that better performing varieties } \\
\text { could be generated to increase productivity in Quality protein maize cultivars basically. }\end{array}$ & $\begin{array}{l}\text { Article History: } \\
\text { Received : 03-07-2015 } \\
\text { Revised : 04-09-2015 } \\
\text { Accepted : 06-09-2015 } \\
\text { Keywords: } \\
\text { Quality protein maize } \\
\text { Variability } \\
\text { Correlation } \\
\text { Genotypes } \\
\text { Traits } \\
\text { Heritability }\end{array}$ \\
\hline
\end{tabular}

\section{INTRODUCTION}

Maize is one of the worlds' three primary cereal crops. It occupies an important position in world economy and trade as a food, feed and industrial grain crop (Girma et al., 2005). Maize demand is projected to increase by $50 \%$ worldwide and by $93 \%$ in sub-Saharan Africa between 1995 and 2020 (FAO, 2007). Though much of the global increase in use of maize is for animal feed, human consumption is increasing and accounts for about $70 \%$ of all maize consumption in sub Saharan Africa. It is also one of the major crops grown by small scale farmers in the semi-arid low rainfall areas of Ethiopia (Aquino, et al, 2001). Some reports of diagnostic surveys indicated that $93 \%$ of the farmers in the lowlands of Ethiopia are maize growers. Maize grain is used for food, sale and marketing, local brewery and the Stover is used for construction, animal feed and domestic fuel (Tilahun and Teshome, 1987).
Maize is currently grown across 13 agro-ecological zones of Ethiopia which together cover about 90 percent of the country. Moreover, it is an increasingly popular crop in Ethiopia. The area covered by improved maize varieties grew from five percent of total area under maize cultivation in 1997 to 20 percent in 2006 (Byerlee et al., 2007). The small-scale farmers that comprise some 80 percent of Ethiopia's population are both the primary producers and consumers of maize. The recent introduction of several new maize varieties in Ethiopia illustrates the potential importance of maize for food security and the contribution of improved maize varieties to country's agricultural sector (Alemu et al., 2008).

Several hundred million people in developing countries rely on maize as their main staple food. However conventional maize (CM) has two significant flaws; it lacks 
the full range of amino acids, namely lysine and tryptophan, needed to produce proteins, and has its niacin (vitamin B3) bound in an indigestible complex. In addition high diets in corn produce a condition known as wetmalnutrition that leads to 'Kwashiorkor' caused by a chronic lack of protein in the diet ( Upadhyay et al., 2009).

Quality protein maize (QPM) developed by the international maize and wheat improvement center (CIMMYT) in the late 1990's produces 70 to $100 \%$ more of lysine and tryptophan and yields $10 \%$ more grain than the most modern varieties of tropical maize (Vasal, 2000). These two amino acids allow the body to manufacture complete proteins, thereby eliminating wet-malnutrition. In addition tryptophan can be converted in the body to Niacin, which theoretically reduces the incidence of Pellagra. QPM offers $90 \%$ of the nutritional value of skim milk, the standard for adequate nutrition value (Upadhyay et al., 2009). QPM varieties have yielded positive results in China, Mexico, and Central America for yield and reduction of wet malnutrition. In Africa, 17(South Africa, Burkina Faso, Cameroon, Ivory Coast, Ethiopia, Ghana, Guinea, Kenya, Malawi, Mali, Mozambique, Nigeria, Uganda, Senegal, Tanzania, Togo and Zimbabwe) countries have introduced and promoted QPM (Upadhyay et al., 2009). QPM varieties adapted to Ethiopia and competitive with grain yield with cultivated conventional maize are insufficient and only few hybrids had been released for planting since recent times. Hence this research proposal was designed with the objective of: To evaluate quality protein maize pipeline varieties in terms of yield and yield related traits at Bako, and to investigate association of yield with its components and other desirable traits.

\section{MATERIALS AND METHODS}

\section{Description of Experimental Site}

The trial was conducted at Bako Agricultural research center. It's located at $9^{0} 6^{\prime} \mathrm{N}$ latitude; $37^{\circ} 9^{\prime} \mathrm{E}$ longitude and 1650 m.a.s.l. The mean annual rainfall is $1200 \mathrm{~mm}$, of which more than 80 percent is received between May and September. The mean minimum and maximum temperatures of the area are 13.7 and $27.9{ }^{\circ} \mathrm{C}$, respectively. The soil is brown clay to sandy-clay loam Nitosols with a pH ranging from 5.3-6.0.

\section{Planting Materials}

Thirteen quality protein maize pipelines and five checks (released hybrids) of maize were used for the trail. The seed source and pedigree of the pipelines are indicated in Table 1.

Table 1: Seed source and pedigree the experimental materials used for the study at Bako in 2013/14 cropping season

\begin{tabular}{llllc}
\hline No. & \multicolumn{1}{c}{ Genotypes } & \multicolumn{1}{c}{ Code } & Seed source & Type \\
\hline 1 & BK02-311-28(F2)B-1/CML144//CML142x144-7-B(F2)-9-2-1-1-2-1-1 & BKO2 & BARC & Pipeline \\
2 & BK02-311-28(F2)B-1/CML144//(GH-132-28)-22-1-6-1-1 & BKOGH & BARC & Pipeline \\
3 & BK02-Z-311-28(F2)B-1/CML144//(CML176xKULENli(F2)-4-3-1-1-1 & BKOKU & BARC & Pipeline \\
4 & CML144/CML159//CML142x144-7-B(F2)-9-2-1-1-2-1-1 & CML1 & BARC & Pipeline \\
5 & CML144/CML159//CML176xKULENli(F2)-4-3-1-1-1 & Kuleni2 & BARC & Pipeline \\
6 & CML144/CML159//BQOORC3\#32-1-2-2-1-1-1 & BQOORC & BARC & Pipeline \\
7 & CML144/CML159//CML142x124-b(113)(F2)-1-1-1-2-2-1 & CML2 & BARC & Pipeline \\
8 & CML144/CML159//CML142x144-7-B(F2)-9-2-1-1-1-1 & CML3 & BARC & Pipeline \\
9 & CML144/CML159//CML142x144-7-b(F2)-9-2-1-2-1-1-1 & CML5 & BARC & Pipeline \\
10 & CML144/CML159//CML142x144-7-b(F2)-9-2-1-2-2-1 & CML6 & BARC & Pipeline \\
11 & CML144/CML159//CML142x144-7-b(F2)-9-2-2-1-1-1-1 & CML4 & BARC & Pipeline \\
12 & CML144/CML159//CML176xKULENli(F2)-3-1-1-2-1-1 & Kuleni1 & BARC & Pipeline \\
13 & Obatanpa-5-4-1-2/(GH-132-28)-22-1-6//CML144 & Obat & BARC & Pipeline \\
14 & BH543 & BH543 & BARC & Released \\
15 & BH542 & BH542 & BARC & Released \\
16 & BH661 & BH661 & BARC & Released \\
17 & AMH760Q & AMH760 & BARC & Released \\
18 & BH540 & BH540 & BARC & Released \\
\hline
\end{tabular}

\section{Experimental Design and Trial management}

The trial consisted of 13 new quality protein maize pipelines and five standard checks as a total of eighteen treatments. The experimental design used was RCBD with three replications. Each variety was grown on $5.1 \mathrm{x}$ $1.5 \mathrm{~m}\left(7.65 \mathrm{~m}^{2)}\right.$ plot area with, $75 \mathrm{~cm}$ between rows and $30 \mathrm{~cm} \mathrm{~cm}$ between plants. The distance between two blocks was $2 \mathrm{~m}$ and $1 \mathrm{~m}$ between two successive plots. The total area of the experimental site was $576.45 \mathrm{~m}^{2}$ (31.5 m length $\times 18.3 \mathrm{~m}$ width). Planting was done using two seeds per hill and $30 \mathrm{~cm}$ apart between hills. Thinning was performed at the three to five leaf stages to attain a final plant density of 44,444 plants ha $^{-1}$. All other management practices including planting, fertilization, weeding and harvesting were performed as per the recommendations for the location.

\section{Data Collection}

The following data were collected on plot bases:

Days to $\mathbf{5 0 \%}$ Anthesis: the number of days from sowing to when $50 \%$ of the plants started to shedding pollen.

Days to $\mathbf{5 0 \%}$ Silking: the number of days from sowing to when $50 \%$ of the plot produced $3 \mathrm{~cm}$ long silk.

Days to $\mathbf{9 0 \%}$ Maturity: The number of days from sowing to when $90 \%$ of the plants in the plot reached physiological maturity which is indicated by the formation of black layer at the bases of ear kernels.

Plant Height (cm): heights of five randomly taken plants from each plot were measured from the ground level to 
Niguse Motuma et alo,

the base of tassel during dough stage and the average was recorded.

Physiological Maturity: Days to maturity were counted as the number of days from emergence to when $50 \%$ of the plants showed black layers on the tip of the kernel.

Ear Height $(\mathbf{c m})$ : ear heights of five randomly taken plants from each plot were measured from the ground level to the node bearing the upper useful ear during dough stage and the average was recorded.

Number of Ears Per Plant: Number of ears per plant from five randomly taken plants was counted and the average was recorded.

Ear Length $(\mathbf{c m})$ : Length of five randomly taken ears from each plot was measured and the average was recorded.

Ear Diameter $(\mathbf{c m})$ : Diameter of five randomly taken ears from each plot was measured using caliper and the average was recorded.

Number of Kernels Per Row: The number of kernels per row from five randomly taken ears per plot was counted and the mean recorded.

Number of Kernel Rows Per Ear: the number of kernel row per ears from five randomly taken ears from each plot was counted and the mean recorded.

100 Kernel Weight: Hundred kernels from each plot were counted by seed automatic seed counter and was weighed using sensitive balance and this was adjusted to $12.5 \%$.

Bare Tips: number of uncovered ears on the tip of the ear were counted at harvest

Plant Aspect: plant aspects were rated on a scale bases of $1-5$ (were $1=$ excellent and $5=$ poor) after physiological maturity.

Ear Aspect: rated on a scale bases of 1-5 (where 1= excellent and $5=$ poor) at harvest time.

Root Lodging: the number of plants whose stalk have been inclined below $45 \%$ from the ground were counted on a plot bases at harvest time.

Stalk Lodging: The number of plants whose stalk have been broken below the upper most ear were considered and counted as stalk lodging.

Grain Yield (kg/plot): The yield of grain each plot was weighed and adjusted to $12.5 \%$ moisture and converted to yield per hectare.

Leaf Area Index: The leaf area index was worked out using the formula given by Sestak (1971). The length and width of the fully opened and physiologically active leaves were measured with a meter road in centimeter on five plants per plot. Leaf area was then calculated by using the formula;

$$
L A=L \times W \times K
$$

Where, LA: Leaf area per plant $\left(\mathrm{cm}^{2}\right)$; Length of leaf $(\mathrm{cm})$; W: Width of leaf $(\mathrm{cm})$ and Factor $(0.75)$ or correction factor

\section{Statistical Data Analysis}

Data was subjected to analysis of variance using SAS (SAS Institute, Inc., Cary, NC). Treatment means were separated by the Fisher's protected least significant difference test at $p=0.05$ (SAS, 2004).

\section{Estimation of Magnitude of Variation}

The phenotypic and genotypic variances were estimated according to the method suggested by Burton and De Vane (1953).

$$
\begin{gathered}
\sigma_{g}^{2}=M S_{g}-M S_{e} / r \\
\sigma_{p}^{2}=\sigma_{g}^{2}+\sigma_{e}^{2} \\
\sigma_{e}^{2}=M_{e}
\end{gathered}
$$

Where, $\sigma_{g}^{2}=$ genotypic variance; $\sigma_{p}^{2}=$ phenotypic variance; $\sigma^{2}=$ =environmental variance; $\mathrm{MS}_{\mathrm{g}}=$ Mean square due to genotypes; $\mathrm{MS}_{\mathrm{e}}=$ Error mean square, and number of replications

The coefficient of variations at phenotypic, genotypic and environmental level variation was estimated using the formula adopted by Johnson et al. (1955).

$$
\begin{aligned}
& P C V=\left[\sigma_{p} / x\right]^{*} 100 \\
& G C V=\left[\sigma_{g} / x\right]^{*} 100
\end{aligned}
$$

Where, $\quad \sigma_{p}=$ phenotypic standard deviation $\left(\sigma_{g+} \sigma_{e}\right)$; $\sigma_{g}=$ genotypic standard deviation; $\mathrm{x}=$ Grand mean for the characteristic x; PCV, GCV= Phenotypic and Genotypic coefficient of Variation respectively .

Heritability in broad sense for all characters was computed using the formula given by Falconer (1996) as:

$$
\mathrm{H}=\frac{\sigma^{2} g}{\sigma^{2} p} \times 100
$$

Where, $\mathrm{H}=$ heritability in broad sense; $\sigma^{2} \mathrm{p}=$ phenotypic variance and $\sigma^{2} g=$ genotypic variance

The heritability percentage was categorized as low, moderate and high as follow by Robinson et al. (1955).

$$
\begin{aligned}
0-30 \% & =\text { Low } \\
30-60 & =\text { Moderate } \\
>60 & =\text { High }
\end{aligned}
$$

Genetic advances (GA) under selection expected genetic advances where for each character at $5 \%$ selection intensity was computed by the formula described by Johnson et al.(1955a).

$$
\text { Genetic Advances (GA) }=k \cdot \sigma_{p} \cdot H
$$

Where: $\mathrm{k}=$ constant (selection differential where $\mathrm{k}=$ 2.056 at $5 \%$ selection intensity); $\sigma_{p}=$ phenotypic standard deviation and $\mathrm{H}=$ Heritability in broad sense.

Genetic advances as percent of mean was calculated to compare the extent of predicted advances of different traits under selection, using the formula

$$
\text { GAM }=\frac{G A}{\bar{X}} \times 100(\text { Falconer, 1996). }
$$


Niguse Motuma et alo,

Where, GAM=genetic advances as percent of mean; $\mathrm{GA}=$ Genetic advances under selection; $\bar{X}=$ Mean of population in which selection will be employed.

The GA as percent of mean was categorized as low, moderate and high as following by Johnson et al. (1955) as follows.

$$
\begin{aligned}
0-10 \% & =\text { Low } \\
10-20 & =\text { Moderate } \\
>20 & =\text { High }
\end{aligned}
$$

\section{RESULTS AND DISSCUSSION}

\section{Viability in Phonological Stages}

There is a high significant difference among genotype for days to male and female flowering date, and female maturity date (Table 2). Genotypes took 80.6-84.3 days for male flowering and 80.6-85.7 days for female flowering. Genotypes $\mathrm{CML}_{2}, \mathrm{CML} 1, \mathrm{BH} 540, \mathrm{AMH} 760 \mathrm{Q}$, Kuleni1, BH542, CML3, BQOOR, $\mathrm{CML}_{6}$, Obat, CML4, $\mathrm{BH} 661, \mathrm{BH} 543, \mathrm{BKOGH}, \mathrm{CML}_{5}$, Kuleni 2 , BKOKU and $\mathrm{BKOKU}, \mathrm{BKO} 2$ were late in male flowering and $\mathrm{CML}_{2}$, BH540, Kuleni 1, CML1, BH542, BQOOR, $\mathrm{CML}_{3}, \mathrm{CML}_{6}$, Obat, Kuleni 2 , AMH760Q, BKOKU, BKO2, CML4, CML5, $\mathrm{BH} 543$ and $\mathrm{BH} 661$ were late in female flowering. However, Genotypes $\mathrm{CML}_{2}$ and $\mathrm{CML}_{2}$ were early in male female flowering (Table 3). From the checks BH543 and $\mathrm{BH} 661$ varieties were late in male flowering or tasseling and took 83.7 and 83.3 days, respectively. However
Sci. Technol. Arts Res. J., July-Sep 2015, 4(3): 18-25

$\mathrm{BH} 542, \mathrm{AMH} 760 \mathrm{Q}$ and $\mathrm{BH} 540$ took relatively less number of days to reach days to flowering.

Table 2: Mean squares due to genotypes and error for

\begin{tabular}{|c|c|c|}
\hline Traits & $\begin{array}{c}\text { Genotypes } \\
\text { (DF=17) }\end{array}$ & $\begin{array}{c}\text { Error } \\
(\mathrm{DF}=34)\end{array}$ \\
\hline Male flowering & 3.5 & $0.83^{* * *}$ \\
\hline Female flowering & 4.9 & $0.74^{* *}$ \\
\hline Female maturity & 16.95 & $2.30^{* * *}$ \\
\hline Plant height & 542.8 & $447.5^{\mathrm{ns}}$ \\
\hline Leaf Area Index & 0.53 & $0.30^{*}$ \\
\hline Ear Height & 288.7 & $414.9^{\text {ns }}$ \\
\hline Plant aspect & 0.12 & $0.03^{*}$ \\
\hline Ears aspect & 0.12 & $0.081^{\mathrm{ns}}$ \\
\hline Stalk lodging & 8.2 & $6.4^{\mathrm{ns}}$ \\
\hline Root lodging & 34.4 & $15.9^{*}$ \\
\hline Bare tip & 8.9 & $4.9^{\text {ns }}$ \\
\hline Ears length & 2.78 & $0.052^{* * *}$ \\
\hline Ears diameter & 0.22 & $0.046^{\star * \star}$ \\
\hline No. of rows ${ }^{-1}$ ears & 7.86 & $4.1^{*}$ \\
\hline No. of kernels ${ }^{-1}$ rows & 2.78 & $0.48^{* *}$ \\
\hline 100 seed weight & 68.2 & $10.98^{* * *}$ \\
\hline Grain yield & 3.75 & $0.72^{* * *}$ \\
\hline
\end{tabular}
grain yield and related traits of quality protein maize grown at Bako

Table 3: Agronomic trait of mean data parameter of thirteen quality protein maize pipelines and five standard checks

\begin{tabular}{llllllll}
\hline NO & Genotype & MFD & FFD & MD & PH & EH & LAI \\
\hline 1 & BKKO2 & 84.3 & 84.7 & 159. & 278.0 & 158.0 & 4.2 \\
2 & BKOKU & 84.3 & 84.7 & 156.7 & 265.3 & 145.7 & 4.7 \\
3 & BQOORC & 82.7 & 83.3 & 154.0 & 278.7 & 161.0 & 4.7 \\
4 & BKOGH & 83.7 & 83.7 & 155.7 & 256.1 & 142.7 & 3.9 \\
5 & CML1 & 81.3 & 82.3 & 159.7 & 278.0 & 157.7 & 4.8 \\
6 & CML2 & 80.7 & 80.7 & 155.0 & 268.7 & 148.7 & 4.3 \\
7 & CML3 & 82.3 & 83.3 & 156.0 & 301.0 & 174.0 & 4.6 \\
8 & CML4 & 83.3 & 84.7 & 159.0 & 294.0 & 162.0 & 4.9 \\
9 & CML5 & 84.0 & 85.0 & 159.3 & 283.7 & 168.0 & 3.8 \\
10 & CML6 & 83.0 & 83.3 & 159.0 & 276.0 & 148.0 & 4.6 \\
11 & Kuleni1 & 82.0 & 82.3 & 154.0 & 291.3 & 165.3 & 4.5 \\
12 & Kuleni2 & 84.0 & 83.7 & 155.0 & 299.0 & 167.7 & 3.9 \\
13 & Obtaba & 83.3 & 83.3 & 154.3 & 276.7 & 153.7 & 4.2 \\
14 & AMH760Q & 82.0 & 84.0 & 158.3 & 256.0 & 171.3 & 4.8 \\
15 & BH540 & 81.7 & 82.0 & 157.7 & 264.3 & 143.3 & 3.4 \\
16 & BH542 & 82.3 & 83.0 & 153.3 & 282.3 & 155.3 & 4.0 \\
17 & BH543 & 83.7 & 85.3 & 159.3 & 262.0 & 164.7 & 4.1 \\
18 & BH661 & 83.3 & 85.7 & 159.3 & 299.3 & 166.7 & 4.4 \\
\hline & Mean & $\mathbf{8 2 . 9}$ & $\mathbf{8 3 . 6}$ & $\mathbf{1 5 6 . 8}$ & $\mathbf{2 8 0 . 0}$ & $\mathbf{1 5 8 . 5}$ & $\mathbf{4 . 3}$ \\
& LSD (0.05) & $\mathbf{1 . 5}$ & $\mathbf{1 . 4}$ & $\mathbf{2 . 5}$ & $\mathbf{3 5 . 1}$ & $\mathbf{3 3 . 1}$ & $\mathbf{0 . 9}$ \\
& CV & $\mathbf{1 . 1}$ & $\mathbf{1 . 0}$ & $\mathbf{0 . 9 6}$ & $\mathbf{7 . 6}$ & $\mathbf{1 2 . 9}$ & $\mathbf{1 2 . 7}$ \\
\hline
\end{tabular}

MFD- male flowering date, FFD- female flowering date, MD- Maturity date, $\mathrm{PH}$ - plant height, EH- ear height, LAI- Leaf Area Index

The genotype took 153.3-159.6 days to maturity. Genotype CML2, BH542, Kuleni1, BQOORC, Obat, Kuleni2, BKOGH, CML3, BKOKU, BH540, AMH760Q2, BKO2, CML4, CML6, CML5, BH543, BH661 and CML2 were late in maturity date. However genotype CML2 and BH542 were early in maturity (Table 3 ). In line with this result Lal and Dhirendra (2014) reported that the existence of significant difference among quality protein maize genotypes, this indicates the existence of sufficient variation in the material studied.

\section{Growth Parameters}

Non- significant differences were observed among genotype for plant and ears height (Table 2). However, the genotypes showed a significant difference for leaf area index (Table 2). On average the genotypes gave a 
Niguse Motuma et alo,

leaf area index of 4.3 , with the maximum recorded from CML4 but not statistically different from almost all the genotypes except CML5and BH540 (Table 3). Significant differences were observed among genotypes tested for plant aspect and root lodging (Table 2). However, nonsignificant differences were observed among genotypes for ear aspect, stalk lodging and bare tip. Plant aspect rating ranged from 2.0 to 2.5 . Generally most of the genotype fell within the range of preference by the breeders for their plant aspect (Table 5). Mbuya et al.( 2010) reported similar results for plant aspect in quality protein maize selected for Savanna agro-ecologies.

\section{Yield and Yield Components}

High significant differences were observed among genotypes tested for number of kernel per ears, ear length, number of rows per ears; hundred seed weight and grain yield (Table 2). Number of kernel per row ranges from 10.21 to 13.79 for $\mathrm{BKO}_{2}$ and $\mathrm{BKOKU}$ genotypes. Thus, genotypes BKO2, AMH760Q, CML6, $\mathrm{CML}_{1}, \mathrm{CML} 3, \mathrm{CML4}, \mathrm{CML}_{3}$. kuleni $1, \mathrm{CML}_{5}, \mathrm{BH} 661$, $\mathrm{BH} 543$, BKOGH, BH540, Obat, BQOORC, BH542, CML2, Kuleni $_{2}$ and BKOKU gave the highest number of kernels per row as compared to the rest genotypes (Table 4). Ear length ranges from 20.2 to 21.1 with an average of $21.2 \mathrm{~cm}$. The maximum ear length was obtained from genotypes CML2, CML $1, \mathrm{BH} 540, \mathrm{AMH} 760 \mathrm{Q}$, Kuleni $1_{1}$, $\mathrm{BH} 542, \mathrm{CML}_{3}, \mathrm{BQOORC}, \mathrm{CML}_{6}$, Obatmba, $\mathrm{CML}_{4}, \mathrm{BH} 661$, $\mathrm{BKOKU}, \mathrm{BH} 543, \mathrm{BKOGH}, \mathrm{CML}_{5}, \quad$ Kuleni2 and $\mathrm{BKO}_{2}$ (Table 4).

On average the genotypes gave 35.0 with the range from 27.3 to 42.7 gram hundred seed weight (Table 4).
Sci. Technol. Arts Res. J., July-Sep 2015, 4(3): 18-25

Genotypes BH542, CML2, Kuleni2, Obatmba, CML3, CML5, BKOKU, BQOORC, BKOGH, Kuleni1, CML6, CML1, CML4, AMH760Q, BKO $2, \mathrm{BH} 543, \mathrm{BH} 661$ and BH540 were identified for their highest hundred seed weight (Table 4). on average the genotypes tested gave $8.4 \mathrm{t} / \mathrm{ha}$ grain yield, with the ranged of 5.8 to 10.1 for BH542 and CML4 genotypes (Table 4) and genotypes BH542, BH543, BH540, BKOGH, BQOORC, BKO2, Obat, $\mathrm{CML}_{5}, \mathrm{CML}_{2}, \mathrm{AMH} 760 \mathrm{Q}, \mathrm{CML}_{6}, \mathrm{BKOKU}$, Kuleni 1 , BH661, Kuleni ${ }_{2}, \mathrm{CML}_{1}, \mathrm{CML}_{3}$ and $\mathrm{CML}_{4}$ were gave better grain yields (Table 4) as compared to the rest genotypes. High grain yield potential was shown in the experiment of QPM Pipelines in CML4 had higher grain yields than the best hybrid check, $\mathrm{BH} 661$, which yielded $9.4 \mathrm{tha}^{-1}$. In line with this result Mbuya et al.(2010) reported that the agronomic performance of other QPM and normal varieties were equal or slightly better than the genetically improved normal varieties currently released or the local farmer variety.

Estimates of Means, Ranges, Phenotypic and Genotypic Coefficients of Variations

In general, quality characters had moderate genotypic and phenotypic coefficients of variability. Hundred seed weight had moderate GCV and PCV followed by grain yield. However, these coefficients variability were very low for ears length. Among the yield and yield related characters number of kernel per row and plant height, leaf area index number of kernel per ears, days to maturity, days to female flowering, days to male flowering, ears length and ears diameter respectively (Table 6).

Table 4: Mean grain yield, ear length ,ears diameter, number of kernel per ears ,number of kernel per row,100 seed weight of thirteen quality protein maize pipelines and five checks (released hybrids of maize)

\begin{tabular}{llllllll}
\hline No & Genotype & EL & ED & NKE & NKR & Gytha & HSW \\
\hline 1 & BKO2 & 21.1 & 21.2 & 34.51 & 10.2 & 7.8 & 40 \\
2 & BKOKU & 21.1 & 21.2 & 33.12 & 13.8 & 9.3 & 33.3 \\
3 & BQOORC & 20.7 & 20.8 & 32.2 & 12.7 & 7.6 & 33.3 \\
4 & BKOGH & 20.9 & 20.9 & 34.12 & 11.9 & 7.5 & 34.0 \\
5 & CML1 & 20.3 & 20.6 & 33.98 & 11.3 & 9.4 & 36.0 \\
6 & CML2 & 20.2 & 20.2 & 35.00 & 13.3 & 8.4 & 28.0 \\
7 & CML3 & 20.6 & 20.8 & 35.57 & 11.4 & 9.9 & 32.0 \\
8 & CML4 & 20.8 & 20.2 & 38.10 & 11.4 & 10.1 & 38.0 \\
9 & CML5 & 21.0 & 21.3 & 34.17 & 11.4 & 8.1 & 32.0 \\
10 & CML6 & 20.8 & 20.8 & 34.72 & 11.1 & 8.9 & 35.3 \\
11 & Kuleni1 & 20.5 & 20.6 & 33.13 & 11.4 & 9.3 & 34.7 \\
12 & Kuleni2 & 21.0 & 20.9 & 34.59 & 13.4 & 9.4 & 28.7 \\
13 & Obtaba & 20.8 & 20.8 & 31.45 & 12.5 & 8.1 & 29.3 \\
14 & AMH760Q & 20.5 & 20.0 & 32.71 & 10.9 & 8.6 & 38.0 \\
15 & BH540 & 20.4 & 21.5 & 32.98 & 12.2 & 7.0 & 42.7 \\
16 & BH542 & 20.6 & 20.8 & 31.92 & 12.9 & 5.8 & 27.3 \\
17 & BH543 & 20.9 & 21.34 & 33.59 & 11.8 & 7.2 & 41.3 \\
18 & BH661 & 20.8 & 20.4 & 36.20 & 11.5 & 9.3 & 41.3 \\
\hline & Mean & $\mathbf{2 0 . 7}$ & $\mathbf{2 0 . 9}$ & $\mathbf{3 4 . 0}$ & $\mathbf{1 1 . 9}$ & $\mathbf{8 . 4}$ & $\mathbf{3 4 . 7}$ \\
& LSD(0.05) & $\mathbf{0 . 3 7}$ & $\mathbf{0 . 3 6}$ & $\mathbf{5 . 9}$ & $\mathbf{1 . 2}$ & $\mathbf{1 . 4}$ & $\mathbf{5 . 5}$ \\
& CV & $\mathbf{1 . 1}$ & $\mathbf{1 . 0}$ & $\mathbf{5 . 9}$ & $\mathbf{5 . 8}$ & $\mathbf{1 0 . 0}$ & $\mathbf{9 . 5}$ \\
\hline
\end{tabular}

EL=Ears Length, $E D=$ Ears diameter, NKR=Number of kernel per rows NKE=Number of kernel per ears, Gytha $=$ Grain yield tone per hectare 
Table 5: Mean value of plant aspect, ears aspect, bare tip, stalk and root logging for 13 QPM and 5 standard checks maize varieties at Bako Agricultural research station 2013

\begin{tabular}{clccccc}
\hline No & Genotype & $\begin{array}{c}\text { Plant } \\
\text { aspect }\end{array}$ & $\begin{array}{c}\text { Ears } \\
\text { aspect }\end{array}$ & $\begin{array}{c}\text { Bare } \\
\text { Tip }\end{array}$ & $\begin{array}{c}\text { Stalk } \\
\text { Logging }\end{array}$ & $\begin{array}{c}\text { Root } \\
\text { Logging }\end{array}$ \\
\hline 1 & BKO2 & 2.2 & 2.3 & 5.0 & 3.0 & 3.7 \\
2 & BKOKU & 2.3 & 2.5 & 2.7 & 3.0 & 2.7 \\
3 & BQOORC & 2.5 & 2.3 & 5.3 & 4.3 & 10.7 \\
4 & BKOGH & 2.5 & 2.5 & 3.3 & 5.0 & 7.3 \\
5 & CML1 & 2.0 & 2.5 & 7.3 & 4.3 & 7.0 \\
6 & CML2 & 2.5 & 2.5 & 6.3 & 6.0 & 9.0 \\
7 & CML3 & 2.0 & 2.5 & 2.3 & 3.3 & 2.6 \\
8 & CML4 & 2.0 & 2.5 & 4.3 & 3.7 & 4.0 \\
9 & CML5 & 2.2 & 2.5 & 3.3 & 5.3 & 6.3 \\
10 & CML6 & 2.2 & 2.5 & 2.0 & 2.0 & 2.7 \\
11 & Kuleni1 & 2.5 & 2.5 & 7.0 & 4.3 & 1.4 \\
12 & Kuleni2 & 2.2 & 2.5 & 2.0 & 5.0 & 5.3 \\
13 & Obta & 2.5 & 2.5 & 4.0 & 4.7 & 9.7 \\
14 & AMH760Q & 2.2 & 2.0 & 2.3 & 4.0 & 5.3 \\
15 & BH540 & 2.5 & 2.0 & 3.3 & 8.3 & 6.7 \\
16 & BH542 & 2.3 & 2.2 & 4.0 & 7.7 & 13.7 \\
17 & BH543 & 2.2 & 2.2 & 3.7 & 3.0 & 5.3 \\
18 & BH661 & 2.0 & 2.0 & 6.3 & 6.0 & 8.7 \\
\hline & Mean & $\mathbf{2 . 3}$ & $\mathbf{2 . 4}$ & $\mathbf{4 . 2}$ & $\mathbf{4 . 7}$ & $\mathbf{2 . 2}$ \\
& LSD(0.5) & $\mathbf{0 . 3}$ & $\mathbf{8 . 4}$ & $\mathbf{3 . 6}$ & $\mathbf{4 . 2}$ & $\mathbf{6 . 6}$ \\
& CV(\%) & $\mathbf{8 . 8}$ & $\mathbf{1 2 . 1}$ & $\mathbf{N S}$ & $\mathbf{N S}$ & $\mathbf{N s}$ \\
\hline
\end{tabular}

LSD=Least significant difference, $\mathrm{CV}=$ Coefficients variation

Table 6: Estimates of range, mean, genetic components of variance, heritability and genetic advance of QPM genotype

\begin{tabular}{lccccccccccc}
\hline Trait & Range & Mean & $\mathbf{S E +}$ & $\boldsymbol{\sigma}_{\mathbf{p}}{ }^{2}$ & $\boldsymbol{\sigma}_{\mathbf{g}}{ }^{2}$ & $\boldsymbol{\sigma}_{\mathbf{e}}$ & $\mathbf{P C V}$ & $\mathbf{G C V}$ & $\mathbf{H}^{2}$ & $\mathbf{G A}$ & $\mathbf{G A M}$ \\
\hline MFD & $80.6-84.3$ & 82.9 & 1.3 & 1.41 & 1.15 & 0.83 & 1.6 & 1.40 & 0.88 & 2.5 & 3.05 \\
FFD & $80.6-84.3$ & 83.6 & 1.4 & 1.68 & 1.44 & 0.74 & 2.00 & 1.70 & 0.86 & 2.97 & 3.55 \\
DM & $153-159$ & 156.8 & 2.7 & 3.1 & 2.7 & 2.29 & 1.97 & 1.72 & 0.87 & 5.55 & 3.54 \\
PH & $256-301$ & 280 & 21.6 & 22.23 & 6.8 & 447.7 & 7.9 & 2.5 & 0.90 & 41.17 & 14.7 \\
LAI & $3.4-4.9$ & 4.31 & 0.6 & 0.64 & 0.33 & 0.30 & 14.8 & 7.6 & 0.05 & 0.007 & 0.16 \\
EL & $71.7-86.2$ & 20.74 & 0.3 & 0.36 & 0.28 & 0.05 & 1.7 & 1.35 & 0.77 & 0.57 & 2.75 \\
NKE & $157-190.4$ & 34 & 2.3 & 2.55 & 1.38 & 4.6 & 7.5 & 4.1 & 0.54 & 2.83 & 8.32 \\
NKR & $51.1-68.9$ & 11.94 & 1.1 & 1.27 & 1.07 & 0.48 & 10.6 & 8.96 & 0.84 & 2.19 & 18.36 \\
Gytha & $5.8-10.1$ & 8.4 & 1.2 & 1.49 & 1.23 & 0.72 & 17.7 & 14.6 & 0.83 & 2.5 & 3.02 \\
HSW & $27.3-42.7$ & 34.7 & 5.3 & 6.29 & 5.34 & 10.92 & 18.1 & 15.4 & 0.85 & 10.99 & 31.7 \\
ED & $20.1-21.4$ & 20.9 & 0.35 & 0.56 & 0.14 & 0.04 & 2.7 & 0.64 & 0.24 & 0.27 & 1.32 \\
\hline
\end{tabular}

Ears Length, Ears diameter, NKR=Number of kernel per rows, NKE=Number of kernel per ears, Gytha =Grain yield tone per hectare, $\sigma_{p}^{2}=$ Phenotypic variance, $\sigma_{g}^{2}=$ genotypic variance, $\sigma_{e}^{2}=$ error variance $P C V=P h e n o t y p i c$ coefficient of variation, GCV = Genotypic coefficient of variation, $\mathrm{H}^{2}=$ Heritability (broad sense), $\mathrm{GA}=$ Genetic advance, $\mathrm{GAM}=$ genetic advance as percent of mean, MFD=Male flowering date, FFD=female flowering date, $M D=$ Days to maturity, $\mathrm{PH}=$ Plant height, $\mathrm{EH}=$ Ears height, $\mathrm{LAI}=\mathrm{Leaf}$ area index and $\mathrm{HSW}=100$ Seed weight

\section{Estimates of Variance Components}

Estimates of variance components for the traits recorded are indicated in Table 6. Male flowering date, female flowering date, days to maturity, plant height, ears height, leaf area index, ears length, ears diameters, number of kernel per ears, number of kernel per row, grain yield tone per hectare, 100 seed weight had exhibited moderate genotypic and phenotypic coefficient of variances (Table 6 ).

Phenotypic coefficient of variability (PCV) values ranged from $1.7 \%$ for ears length to $18.13 \%$ for 100 seed weight, whereas the genotypic coefficient of variability
(GCV) ranged from $1.35 \%$ for ears length to 15.4 for 100 seed weight. In addition, PCV value was generally higher than their corresponding GCV values for all the characters considered (Table 6). According to Deshmukh et al. (1986) PCV and GCV values roughly more than $20 \%$ are regarded as high, whereas values less than $10 \%$ are considered to be low and values between $10 \%$ and $20 \%$ to be medium. Based on this delineation, PCV value was low for number of kernel per row, plant height, leaf area index, number of kernel per ears ,days to maturity, days to female flowering, days to male flowering, ears length ; medium for Hundred seed weight had the moderate and grain yield. 
Niguse Motuma et alo,

Genotypic coefficient of variability (GCV) values were low for number of kernel per row , plant height, leaf area index, number of kernel per ears ,days to maturity, ,days to female flowering, days to male flowering, ears length; medium for Hundred seed weight had the moderate and grain yield (Table 6). The low GCV values of these characters suggest that the possibility of improving these trait through selection expression. The difference between PCV and GCV values was medium for hundred seed weight; grain yield leaf area index and medium hundred seed weight and grain yield the influence of environment on these characters. However, this difference was low for number of kernel per row, plant height, leaf area index, number of kernel per ears, days to maturity, days to female flowering, days to male flowering, ears length suggesting minimal influence of environment on the of the characters, thereby having the highest estimates of heritability. Similar result was reported by Yucel et al. (2006) for days to flowering, plant height and harvest index.

Estimation of Heritability in Broad Sense and Genetic Advance

Estimates of heritability in broad sense ranged from $0.5 \%$ for leaf area index to $90 \%$ for plant height (Table 6). The heritability percentage was categorized as low, moderate and high as follow by Robinson et al. (1955). If heritability of a character is very high, say $60 \%$ or more, selection for such characters could be fairly easy. This is because there would be a close correspondence between the genotype and the phenotype due to the relative small contribution of the environment to the phenotype. But, for characters with low heritability, say $60 \%$ or less, selection may be considerably difficult or virtually impractical due to the masking effect of environment. Considering this bench mark, heritability estimate was high $(>60 \%)$ for hundred seed weight, days to female flowering, Ears length, grain yield, number, hundred seed weight, days to maturity,
Sci. Technol. Arts Res. J., July-Sep 2015, 4(3): 18-25

days to male flowering and plant height. It was moderate $(10-20 \%)$ for the remaining quantitative characters.

Genetic advances(GA) under selection expected genetic advances where for each character at $5 \%$ selection intensity was computed by the formula described by Johnson et al.(1955a). Estimates of GA for grain yield was 2.5 tons ha $^{-1}$ per hectare indicating that whenever we select the best $5 \%$ high yielding genotypes as parents, mean grain yield of progenies could be improved by 2.5 tons per hectare (Table 6). Maximum genetic advance $(>20)$ as percent of mean (GAM) at $5 \%$ selection intensity was recorded for plant height and hundred seed weight (Table 6). Between 0-10genetic advance as percent of mean (GAM) at $5 \%$ selection intensity was recorded for leaf area index, number of kernels per rows, ears length, plant height, grain yield, days to female flowering, days to maturity, days to male flowering, number of kernels per ears and100 seed weight (Table 6).

\section{Estimates of Correlation Coefficients at Phenotypic and Genotypic Levels}

Grain yield is the result of many characters which are interdependent. Breeders always look for genetic variation among traits to select desirable types. Some of these characters are highly associated among themselves and with grain yield. The analysis of the relationship among these characters and their association with grain yield is essential to establish selection criteria (Sing et al., 1990). Estimates of phenotypic and genotypic correlation coefficient between each pair of characters are presented in (Table 7). The magnitudes of genotypic correlation coefficients for most of the characters were higher than their corresponding phenotypic correlation coefficients, except few cases, which indicate the presence of inherent association among various characters.

Table 7: Correlation of grain yield with others characters among 13 QPM pipe lines and 5 checks maize

\begin{tabular}{|c|c|c|c|c|c|c|c|c|c|c|c|c|}
\hline Traits & PH & EH & MFD & FFD & MD & LAI & NKE & NKR & EL & ED & HSW & GY \\
\hline PH & 1 & $0.68^{* * *}$ & $0.08^{\text {ns }}$ & $0.11^{\mathrm{ns}}$ & $0.5^{\mathrm{ns}}$ & $0.03^{\text {ns }}$ & $0.27^{\star}$ & $-0.16^{n s}$ & $0.08^{\text {ns }}$ & $0.11^{\mathrm{ns}}$ & $0.05^{\mathrm{ns}}$ & $0.22^{\mathrm{ns}}$ \\
\hline EH & & 1 & $0.10^{\mathrm{ns}}$ & $0.23^{\mathrm{ns}}$ & $0.04^{\mathrm{ns}}$ & $0.02^{\text {ns }}$ & $0.09^{\text {ns }}$ & $-0.09^{\text {ns }}$ & $0.10^{\mathrm{ns}}$ & $0.23^{\mathrm{ns}}$ & $0.05^{\mathrm{ns}}$ & $0.11^{\mathrm{ns}}$ \\
\hline MFD & & & 1 & $0.79^{* * *}$ & $0.22^{\mathrm{ns}}$ & $-0.005^{\mathrm{ns}}$ & $0.02^{\mathrm{ns}}$ & $0.02^{\mathrm{ns}}$ & $1.00^{\star * *}$ & $0.79^{\star *}$ & $0.08^{\mathrm{ns}}$ & $-0.03^{\text {ns }}$ \\
\hline FFD & & & & 1 & $0.04^{\mathrm{ns}}$ & $0.09^{\text {ns }}$ & $0.11^{\mathrm{ns}}$ & $-0.22^{\mathrm{ns}}$ & $0.79^{\text {ns }}$ & $1.00^{* * *}$ & $0.32^{* *}$ & $0.11^{*}$ \\
\hline MD & & & & & 1 & 0.06 & 0.31 & $-0.52^{\star *}$ & $0.22^{\mathrm{ns}}$ & $0.42^{\star *}$ & $0.62^{* *}$ & $0.16^{\mathrm{ns}}$ \\
\hline LAI & & & & & & 1 & $0.03^{\mathrm{ns}}$ & $-0.14^{\mathrm{ns}}$ & $-0.006^{\mathrm{ns}}$ & $0.9^{\mathrm{ns}}$ & $0.01^{\mathrm{ns}}$ & $0.25^{\mathrm{ns}}$ \\
\hline NKE & & & & & & & 1 & $-0.19^{n s}$ & $0.02^{\mathrm{ns}}$ & $0.11^{\mathrm{ns}}$ & $0.15^{\mathrm{ns}}$ & $0.50^{* * *}$ \\
\hline NKR & & & & & & & & 1 & $0.02^{\mathrm{ns}}$ & $-0.22^{\mathrm{ns}}$ & $-0.51^{* * *}$ & $-0.10^{\text {ns }}$ \\
\hline EL & & & & & & & & & 1 & $0.79^{\star \star \star}$ & $0.08^{\mathrm{ns}}$ & $-0.03^{\text {ns }}$ \\
\hline ED & & & & & & & & & & 1 & $0.32^{*}$ & 0.11 \\
\hline HSW & & & & & & & & & & & 1 & 0.07 \\
\hline GY & & & & & & & & & & & & 1 \\
\hline
\end{tabular}

MFD=Male flowering date, FFD=female flowering date, MD=Days to maturity, PH=Plant height, EH=Ears height, LAl=Leaf area index, Ears length, $E D=E a r s$ diameters, NKE=Number of kernel per ears, NKR= Number of kernel per row, Gytha=Grain yield tone per hectare, HSW=100 Seed weight

\section{Correlation of Grain Yield with other Characters}

Grain yield showed positive and significant association with days to male flowering, days to female flowering, plant height, ears height, and leaf area index, ears length, number of kernel per rows, and 100 seed weight (Table 7). At genotypic level, grain also had positive and high correlation with male flowering date, female flowering date, plant height, ears height, leaf area index, number of kernel per ears, days to maturity, ears diameter except for100 seed weight and number of kernel per rows. Grain yield had negative genotypic correlation with for100 seed weight and number of kernel per rows with plant height (Table 7).

\section{Correlations among other Characters}

Male flowering date had positive and significant phenotypic and genotypic correlation (Tables 7) with days to maturity, plant height, ears height, ears length, ears 
Niguse Motuma et alo,

diameter, number of kernel per ears and 100 seed weight. Female flowering date had positive and significant phenotypic and genotypic correlation with male flowering, days to maturity, plant height, leaf area index, rust, ears length, number of kernel per ears and 100 seed weight. Days to maturity had positive and significant phenotypic and genotypic correlation with plant height, ears height, leaf area index, ears length, ears diameter, number of kernel per ears and 100 seed weight. Pant height had positive and significant phenotypic and genotypic correlation with leaf area index, ears length and 100 seed weight. Ears height had positive significant phenotypic correlation with leaf number of cobs/ears harvest, ear length, number of kernel per ears and 100 seed weight. Leaf area index had positive and significant phenotypic correlation with ears length, and number of kernel per ears. Ears length had positive and significant phenotypic and genotypic correlation with 100 seed weights. Ears diameter had positive and significant phenotypic and genotypic correlation with number of kernel per rows and 100 seed weights.

\section{CONCLUSION}

Thirteen QPM genotypes and five checks (QPM and non-QPM hybrid varieties) were planted in randomized complete block design at Bako to evaluate quality protein maize pipeline varieties in terms of yield and yield related traits, and to investigate association of yield with its components and other desirable traits. In the present investigation, analysis of variance revealed significant difference among the genotypes for all the traits measured indicating the existence of sufficient variation in the material studied. The character LAI, grain yield, 100 seed weight showed moderate PCV and GCV. Days to maturity, plant height, ears height, leaf area index, ears length, ears diameter, number of kernel per rows, days to male flowering, grain yield tone per hectare. This indicates that there is a lesser influence of environment in the expression of characters which are suitable for selection. The character days male flowering date, female flowering date, days to maturity, plant height, grain yield, hundred seed weight, ears length were showed high heritability but low level of variability; hence these characters are not amenable for selection in the present studies.

Based on variability study genotype BH540, BH542, $\mathrm{BH} 543$, Kuleni2, and Obta, was identified as early in maturity, hence these can be used for developing early maturing genotypes. In present studies genotypic and phenotypic correlation of seed yield was positive and significantly related with, grain yield tone per hectare, leaf area index, number of kernel per rows. This suggests that while selecting for improvement in seed yield is performed, this character can be kept in mind provided that the character should show high variability, which is the basis for selection to develop good quality protein maize.

\section{Conflict of Interest}

Authors declared no conflict of interest.

\section{REFERENCES}

Alemu, D.M., Wangi, W., Nigussie, M., Spielman, D.J. (2008). The maize seed system in Ethiopia: Challenges and opportunities in drought prone areas. African Journal of Agricultural Research 3(4): 305-314.
Sci. Technol. Arts Res. Jo, July-Sep 2015, 4(3): 18-25

Allard, R.W.( 1960). Principles of Plant Breeding. John Willey and Sons, New York. 485p.

Aquino, P., Carrion, F., Calvo, R. and Flores, D. (2001). Selected maize statistics. In: Pingali, P.L. (ed.). 2001. CIMMYT 1999-2000 World Maize Facts and Trends. Meeting world maize needs: Technological opportunities and priorities for the public sector. Mexico.

Byerlee, D., Spielman, D.J., Alemu, D., Gautam, M. (2007) Policies to Promote Cereal Intensification in Ethiopia: A Review of Evidence and Experience. IFPRI discussion paper no. 707. Washington, DC: IFPRI.

Burton, G.W. and de vane, E.H. (1953). Estimating heritability in Tall Fescue (Festuca Arundinacea) from replicated clonal material. Agronomy Journal 45: 481-487.

Deshmukh, S.N., Basu M.S. and Reddy, P.S. (1986) Genetic variability, character association and path coefficient analysis of quantitative traits in Virginia bunch varieties of groundnut. Indian Journal of Agricultural Science 56:816821.

Falconer, D.S. and Mackay, F.C. (1996). Introduction to Quantitative Genetics. Longman, New York. 464p.

FAO. (2007). Statistical Databases.[online]. Available at: http://faostat.fao.org/default.aspx. Accessed 1 July, 2007.

Girma Abebe., Teshale Assefa., Hussen Harrun., Tewodrose Mesfine and Abdel-Rahman, M., Tawaha, A.I. (2005). Participatory Selection of Drought Tolerant Maize Varieties using Mother and Baby Methodology: A Case Study in the Semi Arid Zones of the Central Rift Valley of Ethiopia. World Journal of Agricultural Sciences 1(1):2227.

Johnson, H.W., Robinson, H.F. and Comstock, R.E. (1955a). Estimates of genetic and environmenta variability in soybeans. Agronomy Journal 47:314-318.

Robinson, D.C.,. Comstock R.E and Harvey, P.H. (1955). Genetic variances in open pollinated corn. Genetics 40: 45-60.

SAS Institute. (2004). The SAS System for Windows Release 9.01. SAS Institute INC., Cary, NC.

Sastri, A.B.( 1974). Path analysis of yield components in Tobacco. Indian Journal of Genetics 34: 57-58.

Singh, U., Jambunathan, R., Saxena, K., Subrahmanyam, N. (1990). Nutrition quality evaluation of newly developed high-protein genotypes of pigeonpea (Cajanus cajan). Journal of the Science of Food \& Agriculture, 50:201-209.

Tilahun Mulatu and Tacoma Regassa. (1987). Nazret mixed farming diagnostic survey report: Shewa Region. Research Report No. 2, IAR, Addis Ababa, Ethiopia.

Upadhyay, S.R., Gurung, D.B., Paudel, D.C., Koirala K.B., Sam, S.N., Prasad, R.C., Pokhrel, B.B., Dhakal, R. (2009). Evaluation of Quality Protein Maize (QPM) Genotypes under rainfed mid hill environments of Nepal. Nepal Journal of Science and Technology 10:9-14.

Vasal, S.K. (2000). The quality protein maize story. Food and Nutrition Bulletin 21: 445-450.

Zhai and Shao-Wei. (2002). Nutritional evaluation and utilization of quality protein maize Zhong Dan 9409 in laying hen feed. MSc Thesis, Shaanxi 712100, P. R. China, Northwestern Agricultural and Forestry University of Science and Technology, Shaanxi 712100, P. R. China. (M.Sc.thesis)

Yucel, D.O., Anlarsal, A.E. and Yucel, C. (2006). Genetic variability, correlation and path analysis of yield and yield components in chickpea. Turkish Journal of Agriculture and Forestry 30:183-188. 